\title{
'New' nations: Resource-based development imaginaries in Ghana and Ecuador
}

\section{Introduction}

Throughout recent history, the discovery of oil, gas, metals and minerals has provided a series of moments for imagining the development futures of resource-rich states. One modality of this - the articulation of national development plans and strategies - are constructed as particular types of political and economic imaginary for maximising the benefits of resource extraction. In the contemporary period, a language of 'newness' and a reinvigoration of the rhetoric of 'nationalism' has emerged to describe both a return of the state (away from the imperatives of neoliberal governance agendas) in the management of extractive resources and to imagine novel ways of determining and distributing the benefits of those same resources. In Colombia for example, the 5 year development plan, subtitled 'everyone for a new country', is 'aimed at[...]growth[...]outside of the extractive sectors ${ }^{1}$ whilst Ecuador speaks of a development strategy iterated as 'La Patria Nueva' (the new nation). ${ }^{2}$

Yet it remains the case that not only has this discursive emergence of 'new resource nations' been examined critically to a limited degree, but also that studies of the political economy of extractivism and its critique 'neo-extractivism', have, for the most part, failed to emphasise the role of political imaginaries in their arguments. Against this background, this paper critically examines the claims to novelty invoked by proclamations of 'new', resource-led development futures by examining the resource-based development imaginaries of Ghana and Ecuador. In both cases, the governments in these countries discursively mobilise resources in a multidimensional language that (re)asserts national control, energy security as well as more evenly distributed resource wealth.

As the state asserts these development imaginaries with an increased role for itself - so-called 'resource nationalism' - there exists the attendant need to create a sense of legitimacy. In Ghana's case this is through a historical excavation of the discursive, socialist past of nation building in order to legitimate current calls for increased state control of resource revenues as codified, for example, in 'local content law'. In Ecuador, the state is legitimised by imagining a future which attempts to move its economy away from resource dependence and instead invests in education and knowledge production. In its national development plan's own words, it is a strategy which 'aims to turn an economy based on finite natural resources into one based on infinite resources, through scientific[...]knowledge'. ${ }^{3}$ By analysing these two cases, their differences notwithstanding, this paper argues that the study of the political process of nationalising extractive resources must emphasise the politics of language to a greater degree. They show, in different ways, how resource extraction is mobilised as 'an active moment in the construction of specific geopolitical imaginaries' ${ }^{4}$ and they highlight how language is used to legitimate state-led, resource-based development. This point is important because it shows the ways in which development 'imaginaries' are made - national development strategies are framed either with reference to an imagined past marked by reverence (as, we argue, is the case in Ghana), or to the future (as, we will show, in Ecuador).

By highlighting the importance of the political dimensions of language, this paper adds to recent edited volumes which have considered the return of the developmental state in struggles over extractive resource sovereignty from a political economy perspective. ${ }^{5}$ The development imaginaries 
being analysed here can be seen to be representative of the rhetorical ambitions of a 'new politics of development', characterised by structural transformation which has, following a wave of postneoliberalism in Latin America, defined the development agenda in Africa in the current decade. ${ }^{6}$ In order to show the ways in which the historical discourse of state-led development is repackaged and mobilised to imagine national, resource-based development futures, two significant bodies of text are analysed. In the Ghanaian context, we analyse a sample of 'State of the Nation' parliamentary addresses made between 2001 and 2015, in particular focusing on the last 5 years of these which followed oil and gas discoveries in the country. In the second instance, we examine developments arising out of Ecuador's five year development plan, the Good Living National Plan 2013-2017. This builds on the vision found in the Good Living National Plan 2009-2013. Prior to the election of Rafael Correa in 2006 and the subsequent new Constitution of 2008, there was a period of intense political and economic instability, with seven presidents in the decade 1996-2006, alongside an ideological climate which militated against long-term, transformative development planning.

Structurally, we proceed in section 2 by outlining critical work on 'new developmentalism' in extractive states. By engaging with this work, we show how a cultural critique can strengthen and support a burgeoning literature that has exposed the limitations of the discourse of state-led extractivism seen as 'progressive' or 'sustainable'. Section 3 critically details the case of Ghana, whilst section 4 engages with the Ecuadorean context. We conclude with some thoughts on what an expanded reading of the 'return of state' - one that emphasises the role of political imaginaries means for nation-states following development models based, in one way or another, on resource extraction.

\section{Neo-extractivism: extending the theory conceptually and empirically}

Historically, the ways in which the export-led growth model based on high prices for extracted commodities has been critiqued are multifarious. These have ranged from Raul Prebisch's seminal treatise from the 1950s that warned in favour of industrialization and against the perils of dependency on primary commodity exports ${ }^{7}$ to the more recent, heavily theorised debates which have centred on the contention that resource abundance counter intuitively represents a curse. ${ }^{8}$ Although the conclusions reached by these studies vary both in their empirical focus and the relative strength of the relationship between resources and growth, they are all written with a heavy (political) economic bias. This standpoint is symptomatic of a literature which has tended to eschew critical engagement with the cultural ways in which resource presence and relative abundance is imagined and rhetorically mobilised by the state in planning for sustainable development.

In the contemporary period, resource extraction retains a strong association with forward-facing imaginaries of 'progress' and the potential for favourable economic growth. From the recent narrative trope that Africa is 'rising' ${ }^{9}$ to recent literature that sees the continent's 'new oil' as part of a 'future fortune ${ }^{10}$ the implication is that development and resource extraction can be viable and progressive bedfellows. Similarly in Latin America, resource extraction, complete with its vast assemblages of human, non-human and infrastructural components, continues to form both a present and future 'extractives complex' in spite of shifting geographies. ${ }^{11}$

At the global policy level, the United Nations Economic Commission for Africa (UNECA) announced in the opening paragraphs of its 2015 'Economic Report on Africa' that, 'industrialization promises to 
address the paradox [of poverty coexisting with robust growth] by promoting...efficient utilisation of abundant physical and mineral resources and in the process eliminate poverty and hence structurally transform African economies'. ${ }^{12}$ In seeking to address the inequalities brought about by neoliberal development in resource-rich states, such a position almost perfectly defines the formation of the contemporary post-neoliberal condition of 'new developmentalism' or 'new/neoextractivism'. This consensus has been premised on 'the economics and politics of natural resource extraction...fostering a more socially inclusive form of development ${ }^{\prime} .{ }^{13}$ It is also emblematic of the returning presence of the state in the resource politics of export-led economic growth ${ }^{14}$ which, in marking a supposed departure from previous iterations of the developmental state, has ushered in 'new mechanisms for social inclusion and welfare'. ${ }^{15}$

As Burchardt and Dietz recently establish, neo-extractivism is characterised 'by the renaissance of the developmental state, which[...]appropriates extra revenue and mediates between diverging interests[...],acts as an agent of development and[...]creates political legitimacy for itself through democratic elections and a development narrative'. ${ }^{16}$ Although neo-extractivism as a term remains a fairly recent iteration, predominantly popularized through the work of Eduardo Gudynas ${ }^{17}$, conceptually it has been predominantly analyzed as either a challenge to development theory ${ }^{18}$ or as an effective alternative to the neoliberal economic ordering of the extractive economy. ${ }^{19}$

For some critics, it continues, rather than challenges, the patterns of accumulation previously associated with neoliberal resource extraction. Indeed, whilst the shift towards the post-neoliberal state promised to begin a 'twenty-first century socialism' and, in the words of Ecuadorian President Rafael Correa, to 'end the neoliberal night' ${ }^{20}$, substantive changes to the development model which it seeks to replace are lacking. Thus, the argument follows that in spite of the strong rhetorical shift to the political left, the structural transformation associated with neo-extractivism has failed to materialize. Rather, it can be seen as 'continuity at change ${ }^{21}$, firmly entrenched within a logic of old extractivism despite a break from 'traditional' neoliberalism ${ }^{22}$ and, more radically, part of the 'imperialism of the twenty-first century'. ${ }^{23}$ The latterly deployed language of imperialism echoes Harvey's geographical treatment of 'accumulation by dispossession' ${ }^{24}$ and is applied to cases in Bolivia ${ }^{25}$ as well as Latin America more generally. ${ }^{26}$

However, these studies share two trends in terms of their foci, one conceptual and one empirical, which this paper seeks to address and expand upon. First, although political legitimacy is created through 'a development narrative' (as noted in the Burchardt and Dietz's definition of neoextractivism), largely missing from these analyses is any critical engagement with how that process of legitimization takes place. It ignores the assertion that the construction of the 'neo-extractivist' state is simultaneously and ontologically cultural and political where the politics of language itself and a 'concern with meaning making' is emphasised ${ }^{27}$. The act of foregrounding the discursive modalities of legitimation as we do here through the study of development narratives in Ghana and Ecuador, is to attend to this shortcoming.

At the policy level, the importance of legitimisation is usually only suggested implicitly. However, proceedings at the 2013 UNECA conference made this crucial point more explicit where it asserted that 'the Developmental State must be based on legitimacy'. ${ }^{28}$ Our studied cases of Ecuador and Ghana both select and investigate the ways in which the national imaginary legitimises particular approaches to extracting resource rents. Collectively, they emphasise the political nature of 
'extractive imaginaries' - to be thought of here as an adaptation of work in science and technology studies as 'powerful cultural resources that help shape social responses to [resource extraction]. ${ }^{29}$ Although imaginaries never fully determine development policy, they nonetheless help to shape it, infused as they are by cultural ways of understanding the world geographically, environmentally and geopolitically. For example the Peruvian Amazon's construction as 'marginal and empty', discursively positioned in contrast to a 'coastal mestizo society which is seen as the cradle of the nation' can be read as part of a geographic imaginary that has led to misrecognition of Amazonian voices from equitable policy treatment ${ }^{30}$. Additionally, competing ways of imagining nature have led to a politics of contention and environmental struggle in numerous cases ranging from Central Appalachia ${ }^{31}$ to contemporary Bolivia. ${ }^{32}$ Our intention is to show how the analysis of political imaginaries can strengthen the study of neo-extractivism.

In addition to this conceptual contribution, this paper secondly attends to an empirical lacuna - the general absence of cases from outside of Latin America. Across the literature, neo-extractivism is parsed as a 'Latin American phenomenon' ${ }^{33}$ and is used as short-hand for the 'pink tide' of emerging leftist governments on the continent in recent years. ${ }^{34}$ However, by focusing on the increase in the rhetorical importance given to state involvement in resource based development, it is possible to think through the concept's utility more globally. The present study addressing of the Ghanaian context adds to a nascent literature that has only just begun to address the new geographies of neoextractivism that range from Africa ${ }^{35}$ to the global North. ${ }^{36}$ Even in these cases though, neoextractivism is usually described in a negative register, dismissed as little more than old-style extractivism.

This article proceeds by analysing the iteration of development plans and pathways in Ghana and then Ecuador. In the following section, Ghana's post-independence 'State of the Nation' addresses are analysed before Ecuador's development plan of 'La Patria Nueva' is interrogated in section 4. By examining the cultural dimensions of national development strategies more prominently, both instances offer critiques of a narrow political-economy reading of neo-extractivism. In the Ghanaian case, we first highlight how particular mechanisms and themes are used to legitimate the state's extractive policies. Then, in the following case from Ecuador, the contemporary possibilities of creating an 'infinite' knowledge based economy out of a 'finite' reliance on extraction are assessed in order to show how a language of legitimation translates into substantive, structural transformation in that country.

\section{The Discourse of Legitimacy: Structural transformation in Ghana's 'State of the Nation' addresses}

'Ghana, the black star of Africa, is on the rise again! ${ }^{37}$

State of the nation (SOTN) addresses describe the comprehensive speeches given by a country's head of state to its legislature on an annual basis and reflect upon its economic, social and environmental standing. As such, they can be seen as perhaps the key discursive moment for imagining a country's development future and, in many cases, are often framed with reference to specific national development plans and strategies. In Ghana, we studied all SOTN addresses between their introduction by President John Kufuor in 2001 and their most recent iteration in 2015. We focus much of the analysis on those addresses made between 2010 and 2015, where oil 
discovery has been used as a moment to most explicitly imagine the 'new' nation. By privileging a cultural critique of these speeches, we identify three crucial discursive turns that show how the neoextractivist nation is imagined and legitimised by the Ghanaian state. Firstly, neo-extractivism is associated with both the rebirth and progress of the nation - or, what we term a 'politics of potential'. Secondly, religion and cultural tradition is used to 'bless' development futures founded on state-led resource extraction. Finally, the discourse of a unified 'single-nation' is mobilised in order to legitimise neo-extractivist development. In order to analyse the discursive strategies of the resource state, we draw upon Van Leeuwen's categorization of a language of legitimation ${ }^{38}$ which shows how extractive 'systems of authority' (such as the Ghanaian state) 'attempt to establish and cultivate the belief in its legitimacy'. ${ }^{39}$

As Van Leeuwen asserts, in delineating his model for analysing the strategies of legitimation by the state (and other dominant actors), 'language is...the most important vehicle for these attempts' ${ }^{40}$ In the following subsections, it is shown how such a focus on the politics of language can highlight emergent themes that highlight the ways in which the economic imaginary of an extractive-led development future is defined and legitimised.

\section{a) The politics of potential}

'Keep quiet and listen. The change and transformation is starting. ${ }^{41}$

An almost universal theme that runs throughout the discourse of resource politics in SOTN addresses in Ghana is the forward facing and transformative possibilities that extractive-led development offers. Whether this is in reference to recent oil discoveries or the use of gold stocks, resources are a foundational part of the country's development imaginary. Highlighted in terms of their newness, the language of national, resource-led extraction is part of what we term here as a 'politics of potential'. For example, President Mahama's 2014 SOTN begins by imagining the structural 'change' of Ghana's contemporary economy to be in part defined by greater national control of its resource sectors; it will 'propel us forward, as a nation, to all that lies ahead'. ${ }^{42}$ This language of potential simultaneously includes notions of erstwhile underdevelopment and the promise and future possibility for resource-based growth.

Yet, this narrative of 'propulsion' is discursively mapped onto a linear narrative of progress by invoking modernisation theory; As the 2010 SOTN address asserted, 'exploitation of crude oil and gas are positioning Ghana for a major industrial take-off'. ${ }^{43}$ What follows in this speech are a series of measures for resource-led growth that strongly echo Rostow's 'stages of growth' thesis (Rostow 1971). Notwithstanding the longstanding and widespread academic critiques of the model, the repeated references made to 'accelerated resource development' ${ }^{44}$ reinforce and legitimise this position of aspiration. It is an example of 'theoretical rationalization' whereby resource based growth is referenced by the state as 'a natural order of things ${ }^{45}$. In other words, (state) development of newly discovered extractive resources is presented as a necessary condition for growth. To not follow this pathway is to display 'a fallen sense of selflessness and patriotism' ${ }^{46}$, and is, by extension, a politically unsustainable position. By accepting state control and management of resources as 'natural', the economic strategy of resource led growth is both reproduced and unquestioned. 
The repeated forward-facing references found in this politics of potential attempt to place and represent resources as real, exploitable and controllable. The discourse of extractive-led development both imagines and then represents its (finite) natural resources as full of economic promise not only in Ghana but also across the African continent. For example, senior political figures in Tanzania invoke the potential of gas to 'change the country into a better place to live'. ${ }^{47}$ Referencing oil's possible impact on Uganda's agricultural development, 'the message of positivity should be taken out to the streets that...the black gold under the ground can be transformed into green gold above the ground'. ${ }^{48}$ The 'future' in these proclamations is nearly always articulated without reference to an upper time limit, promising an open-ended imaginary of sustainable resource wealth but perhaps belying a lack of certainty and control. As we are reminded from cultural studies, it is precisely in these linguistically undefined spaces where ideas of 'nationness...or cultural value are negotiated'. ${ }^{49}$ Such discursive vagueness is, of course, politically expedient in so far as it allows aspirational claims to development to be made freely and without evidence. The freedom to make political claims is enhanced by the materiality of resources mobilized for extraction; metals and minerals are often out of sight deep underground, whilst gas and oil discoveries such as those in Ghana may be offshore and 'unseen'. Their relative 'invisibility' allows the state to project hope and prosperity out of the future promise of resource wealth as well as from resource extraction in the present.

Future-facing iterations of resource-led development also have a relationship with development histories and the past. In Ghanaian SOTN addresses, for example, repeated references invoke the successes and rhetorical strength of the nation's first president and national icon Kwame Nkrumah in order to legitimise the present and future trajectories of its development. Thus, Nkrumah's legacy is recalled as being 'of blessed memory, seeking to break this vicious cycle [of private controlled resource]' by 'establishing numerous state-owned industries' ${ }^{50}$ In the present context of resourcebased development, it follows that it is a political imperative to 'pursue Nkrumah's dream of an integrated bauxite and alumina industry. ${ }^{51}$ This, too, is a form of authority legitimation where references to status figures with historical value help establish the legitimacy of present policy choices. It is the very fact that Nkrumah-as-expert recommended a certain approach to Ghanaian resource policy, rather than argument or evidence, which renders it 'a good idea'. ${ }^{52}$ In other words, legitimacy is provided by status rather than the content of the policy.

\section{b) Religious and traditional authority for a 'blessed' resource nation}

A second major way in which the state legitimates resource-based development is through discursive strategies that emphasise the role of religion. Recent scholarship has noted how development studies and religion both concern themselves with the idea of prosperity and progress in one form or another. ${ }^{53}$ In Ghana, proclamations from the president that link the idea of resourceled development on the one hand and religious will on the other are commonplace. For example, speaking about the national oil development bill in 2014, Ghana is urged that:

'we cannot falter and we must not be afraid, because God is on our side, and the holy book says if god is for us, who can be against us' ${ }^{54}$

Such a reference resurrects the decades-old assertion that religion provides a moral framework for understanding processes of development. ${ }^{55}$ In other words, it 'provides sets of norms with which to assess [development's] legitimacy and validity'. ${ }^{56}$ From this perspective, the discursive positioning of 
religious assent for state-controlled resource extraction recognises that religious belief is a fundamental part of the value system that informs people's understanding of the development process. As Deneulin and Rakodi point out, 'because religion is an important force that shapes people's values, what they consider worthwhile and valuable, it is integral to social, political and economic life'. ${ }^{57}$

Throughout the speeches studied, repeated references are made to the 'blessing' and 'divine right' of Ghana to mobilise its extractive resources sector for the benefit of growth. ${ }^{58}$ This is the case regardless of the specific resource under consideration. In examples ranging from the historical discoveries of gold, oil and natural gas, the message is made clear: Ghana must follow an extractivist logic precisely because 'God is willing'. ${ }^{59}$ Here, 'God' functions as the ultimate role model, expert and guide for resource-based development through a form of authority legitimation. The state has God's blessing and so, naturally, is laying out the right pathway for development to take place. As far back as 2003 , the president urged the nation to 'keep praying' for offshore oil, ${ }^{60}$ in the hope of guidance over apposite pathways to development. This echoes a political background in the last decade that has seen widespread 'thanks' given to God for his 'gift' of oil to Ghana. ${ }^{61}$

Religion's discursive coupling with extractivism is a more specific extension of recent scholarship that has focused on the relationship between religion and nationalism. Addressing a gap in the literature on nationalism more generally, this work highlights the absence of religion from theorizations of nationalism that have focused on economic factors. ${ }^{62}$ It foregrounds, for example, the instrumental ways in which 'national leaders try to draw on religion to create a cohesive public body'. ${ }^{63}$ In the context of this paper, the Ghanaian presidency repeatedly invokes religion to legitimate local content policy (LCP) in the country's nascent oil sector. LCP is only one strategy used to structurally transform the economy in Ghana but it aims to maximise and capture benefits from the extractive industry sectors. However, it is not legitimized merely through appeals to economic efficiency but also through its approval by divine forces. As the president stated in 2013, 'we will proceed with local content legislation to ensure Ghanaian participation in this blessing of nature God has bestowed on us'. ${ }^{64}$ In this regard, LCP is not only a series of interventions developed in the best interests of the nation, but also consecrated by God. Thus, the implication is that the act of failing to support LCP is to simultaneously miss out on its economic benefits and to turn down an invitation to 'participate' in God's 'nature'. It serves to discursively legitimize so-called resource nationalism, coupling 'resources' and 'nation' in such a way as to unify Ghana's approach to its development.

\section{c) Rationalising the one-nation resource state}

A third way in which Ghanaian state of the nation addresses helps to legitimise a neo-extractivist imaginary is through the validation and reification of the nation itself. Ghana is conceptualised and articulated as 'one nation', united in its approach to resource based development. For example, while discussing oil and gas discoveries it was made clear how a 'commitment to a Ghana-first approach' to resource management should be enacted 'wherever the national interest can better be served that way'. ${ }^{65}$ In discursively positioning the nation and its 'interest' in the singular, it recalls the enduring strength of nationalism as 'the most universally legitimate value in the political life of our time' ${ }^{66}$ It evokes the past of discursive and substantive nation-building undertaken by Nkrumah and others which is heralded as a 'proud time' which recalls 'our leading role in African liberation'. ${ }^{67}$ 
In the 2014 state of the nation address, President John Mahama explicitly stated that the notion of 'responsible citizenship' is important to pushing through structural transformation of the economy. ${ }^{68}$ He concludes that 'Ghanaians are, at our core, the same people we were on March 6, 1957 when we became a free nation' and that 'being made in Ghana' should be seen as a source of 'pride'. ${ }^{69}$ The implication is that a more inclusive value chain for resource extraction with greater 'local content' is a continuation of the guiding principles of what it means to be Ghanaian as laid out by its celebrated founding father(s). Thus, it follows that 'the pettiness of politics' should be avoided, and that questioning new directions for resource policy is tantamount to being 'unpatriotic' - an untenable position for dissenters. In linguistic terms, it represents another form of 'rationalisation legitimation' where reference to the goals of social action is presented as a natural order of things and where disavowal to those aims is unthinkable. One state of the nation address explicitly details these ramifications:

'The instant we allow ourselves to fall prey to...the small-mindedness of doomsayers and people who actively wish for the failure of any action or policy intended to lift Ghana up [such as oil and gas policy], we turn our backs on that love and in so doing, we betray our own homeland'. ${ }^{70}$

Having shown some of the ways in which the state discursively legitimates a commitment to resource extraction, the following section focuses on Ecuador and offers a related example of how, in substantive terms, 'new' resource nations are imagined. It shows how the development imaginary of structural transformation in Ecuador moves away from resource extraction and towards a knowledge economy in its attempts to both discursively and substantively construct the 'new nation'.

\section{Ecuador: Constructing La Patria Nueva}

Since the production of oil began in 1972, Ecuador has been an oil-dependent country. Between 2000 and 2012 oil made up fifty-five per cent of total exports and twenty-nine per cent of government revenues. ${ }^{71}$ Observers have noted its centrality to the political identity of the nation where it 'has shaped visions of the boundaries, potentialities, and character of the Ecuadorian nation-state'. ${ }^{72}$ Much international academic writing focuses on its current form of neo-extractivism in the present timeframe, and, in particular, on its impact on indigenous communities, on the environment, and often from a post-development perspective. ${ }^{73}$ However, what is not highlighted is the government's long-term, strategic vision for the future. This is the structural transformation of the economy from a primary commodity exporter to a knowledge economy over a forty to sixty year period. ${ }^{74}$ As the government's national development plan 2013-17 states 'our aim is to ... leap forward from an economy of finite (material) resources-based economy to an economy based on infinite-based resource: knowledge. ${ }^{75}$ In other words, 'the government aims to employ extractivism to abandon extractivism. ${ }^{76}$

Building on the previous section's analysis, it is shown here how, since coming to office in 2007, the government of President Correa has translated its ambitious vision into practice. This development imaginary rejects the country's history of dependency in all its forms, including knowledge dependency, in order to experience a second independence ${ }^{77}$. Ecuador is home to one of the most biodiverse habitats in the world and the aim is to exploit these 'natural laboratories' with the country's own human talent. ${ }^{78}$ Yet there remains considerable debate about how it can navigate its 
own social knowledge imaginary of a public commons within a global cognitive capitalism which privatises and commodifies knowledge. As Ramirez Gallegos, Secretary of Higher Education, Science, Technology and Innovation, has argued, the challenge is to break the only role that is reserved to the Southern countries... of being consumers of the science, creation and innovation of the North. ${ }^{79}$

Such structural transformation has been made possible, in the first instance, by re-constructing the concept of a democratic developmental state, a characteristic part of the neo-extractivism undergoing a general 'renaissance' across the continent. ${ }^{80}$ The Ecuadorian state emphasises notions of autonomy, capacity and legitimacy. It has stressed the importance of autonomy vis a vis international actors for a peripheral development state by setting up the Commission for Public Credit Audit (CAIC) in $2007 .{ }^{81}$ On the basis of its report, the government re-negotiated its debt payments, saving the country $\$ 2.2$ billion plus $\$ 7$ billion in interest until 2030. In 2006 debt servicing was $24 \%$ of the budget, by 2012 this was $4 \%{ }^{82}$ Having 'won back' some sovereignty and resources, the government built the bureaucratic capacity of the state to plan and implement a development imaginary. As its 2013-17 national plan states:

'We are emphasizing planning to avoid duplicating efforts and wasting resources, as occurred and so damagingly held us back during the neoliberal period. Planning was neglected and minimized during that period. Those governments ignored planning because of their ideology, but also because of their economic interests. ${ }^{83}$

Finally, Ecuador's embracing of a new developmentalism asserts its legitimacy through both democracy and the material success of its developmental project. President Correa was re-elected in 2013 on an absolute majority of the vote, 53 per cent, with a 34 point lead over his nearest rival. His party secured 100 out of the 137 seats in the National Assembly. Voter turn-out was over 80 per cent in both elections. In July 2015 Correa's approval ratings stood at 66 per cent. ${ }^{84}$ As Ecuador's Culture Minister, Guillaume Long, summed up recently: 'The government's ongoing popularity ... stems from the program of Ecuador's Citizens' Revolution, which since 2007, has been successfully driving economic growth and social inclusion through public investment. In doing so it has rejected the neoliberal dogma'. ${ }^{85}$ 'Economic development as a primary logic of legitimacy' is central to a developmental state. ${ }^{86}$

In Ecuador, the flagship project of the government's knowledge economy is the creation of a new city of knowledge, Yachay, named after the indigenous Quechua word for knowledge. It is the first planned city in Ecuador's post-colonial history and is located 115 kilometres north of the capital, Quito. It is a thirty-year project with over $\$ 1$ billion of investment and has been described by President Correa as the most important achievement of his government. As Moser et al point out: 'Building new planned cities is a strategy used by states to stimulate economic development as well as instil a sense of loyalty and pride in the population' ${ }^{87}$ By bringing together the symbolism of tradition, authenticity and indigeneity inferred by Yachay with a forward-facing 'triple helix' urban hub of academic, private and public sector research and innovation, legitimacy is asserted. At the heart of this structural transformation lie the links between past and future, a strategy employed elsewhere in Ecuador. For example, Burbano de Lara has shown how Correa links building la Patria Nueva to the same historic mission of Bolivar and Alfaro in liberating the continent. ${ }^{88}$ Many observers have discussed how the national development plans have been inspired by the Andean indigenous worldview of Sumak Kawsay. ${ }^{89}$ 
Yachay has drawn closely on South Korea's master planned city, Songdo, within the Incheon Free Economic Zone (IFEZ). IFEZ is South Korea's largest and oldest free economic zone, established in 2003 and due to be completed in 2020 with the aim of becoming one of the top three economic zones in the world. Ecuador signed a Memorandum of Understanding with IFEZ in $2010 .{ }^{90}$ It has drawn on South Korea's broader development experience through the development cooperation Knowledge Sharing Programme. This has provided Korean expertise on various sectors, including research and development, human resources and biotechnology. ${ }^{91}$ In making these connections, the 'national' discourse of Ecuador's development imaginary comes into conversation with the global imperatives of free economic zones. ${ }^{92}$

At the heart of Yachay is a new research intensive university, Yachay Tech, which will be surrounded by research institutes and a technology park with a focus on agriculture and biotechnology. At Yachay Tech's official opening in March 2014, Ecuador's Higher Education, Science, Technology \& Innovation Minister, Ramirez Gallegos, proclaimed:

'If the petroleum boom of our country was born on 26 July $1972 \ldots$ we hope that today Monday 31 March 2014 generates a new boom, the knowledge boom... Here the new nation is being born, here we are overcoming the extractivist economy ${ }^{93}$

Yachay is, to a certain extent, inspired by the California Institute of Technology (Cal Tech), the world's most highly ranked university for the last four years. ${ }^{94}$ Indeed, despite Yachay's obvious association with national identity, the university is global in both its aims and composition, reflecting the government's development view that 'transforming the productive structure assumes interaction with the scientific and technological cutting edge. ${ }^{95}$ The president, chairperson and vicechairperson of the Board of Trustees, are all current engineering faculty at Cal Tech, who visit Yachay Tech. The Board's president, Jose Andrade, argues that 'like me, all world class academics work at several entities. Our role is to connect the University with the world and to be able to do that we need to be with one foot in and the other foot out. ${ }^{96}$ How that is successfully navigated to create an Ecuadorian scientific powerhouse to change the structure of the economy is strongly debated within the country and was one of the reasons for the demise of the former rector of Yachay Tech. ${ }^{97}$

Yachay is one aspect of a wider, far-reaching revolution in Ecuador's higher education system, instigated by the Correa government and guided by two principles: improving both research and teaching quality, and ensuring access to previously excluded groups such as indigenous Ecuadorians and Afro-Ecuadorians. Both these principles had been abandoned under decades of neoliberalism. ${ }^{98}$ Ecuador now invests 2.1 per cent of GDP in higher education, higher than the OECD average and the highest proportion in Latin America. ${ }^{99}$ The 2008 Constitution established the right to free education from primary school to university level for all citizens. In addition to Yachay, the government has created three more new universities: the University for the Arts in Guayaquil, a University of Education in Azogues and Ikiam (Shuar for forest) University of Biodiversity in Tena. Historically, Ecuador's university system has focused on teaching, less than five per cent of staff have PhDs and there has been little research funding or culture. ${ }^{100} 10,000$ students have now received full scholarships to study at universities abroad in North America, Latin America, Europe and Asia. Ecuador provides the highest number of scholarships per capita in the continent and third highest in the world. Two thirds of the scholarships have been for postgraduate studies and nearly all the students have returned to work in Ecuador. ${ }^{101}$ 
Undoubtedly, even as the government chose to celebrate eight years of the Citizens Revolution at Yachay and designated 2015 the Year of Knowledge in Ecuador, many questions remain. The discourse of Ecuador's twenty-first century developmentalism is a confluence of many sources, internal and external. Its development plans have been strongly influenced by the discourse of international heterodox economists whilst the government's promotion of a knowledge economy has to confront a highly competitive and commodified world of neoliberal academia. Is there an intrinsic contradiction between using oil to fund a post-oil economy, that the continuity of extractivism will reproduce the same prevalent socioeconomic and power logic'? ${ }^{102}$ Given the international community's eschewal of the government's innovative environmental compensation scheme, what other alternatives exist to fund the transition to a post-oil economy? ${ }^{103}$ How can the government pursue a social knowledge economy under the pressure of cognitive capitalism? Can the government now maintain higher education as a public good or will it reproduce academic capitalism with its innate competitive and commodification processes? ${ }^{104}$ Will the Right take power either via orchestrated instability or at the 2017 election and reverse the Citizens Revolution? Will the government's Yachay vision succeed in its own terms? What is clear is that the strong discursive and substantive commitment to move away from extractivism towards a knowledge economy is an attempt to liberate Ecuador from a cycle of dependency in which 'without independence there is no Nation. Yachay is building the Patria' ${ }^{105}$ Speaking at the University of Santiago in Chile on accepting an honorary doctorate in recognition of the country's educational reforms, President Correa noted Ecuador's exceptional investment in higher education and asked 'this is our future, why not invest in it? ${ }^{106}$

\section{Conclusions}

The two case studies of Ghana and Ecuador, though evidently different in terms of their political economic histories, have been used in this paper with the same purpose. Namely, they have both sought to show how the study of so-called neo-extractivism can be strengthened by including a cultural dimension which highlights the political importance of language. We have shown how language itself is simultaneously used to define 'new' resource nations, imagine new development futures and to legitimise the particular resource policy directions required in order to bring structural change into being. Emphasising the importance of the politics of language strengthens the literature on the 'return of the state' in resource politics and geographies. In the context of this paper, we have highlighted the role that resource extraction plays in the construction of development imaginaries. Development plans and political statements and actions are shaped and legitimised by mobilising a discursive engagement with 1) time and 2) with an unwavering belief in the value of the 'nation' as a unifying and enabling mechanism for policy formation.

In the first instance, the discursive engagement with time is noticeable in the political imaginaries of both Ecuador and Ghana where it is encountered and mobilised in two directions - forwards and backwards. In Ecuador, the politics of Buen Vivir is invoked in imagining a development future based on a knowledge economy but fuelled by the extractive economy. It is not a short term future of the type usually seen in '5-year plans' but rather a prospect that is imagined several decades away. The Ecuadorian experience is both a classic restatement of social democratic developmentalism which is state-centric, redistributionist and sovereign, as well as innovating on a long-term transitional strategy to become a post-extractive knowledge economy. In Ghana, a similar 'politics of potential' is evident but this time with its natural resources imagined as an ongoing motor for development. 
However, this time the promise of future economic progress is legitimised by invoking a backwardsfacing past of nation-building with its strong rhetorical reproduction of the tenets of nationallycontrolled resources.

In the second instance, the nation is imagined as a unified and singular unit of analysis. Implicit in this discursive strategy is the understanding that the structural transformation of resource sectors towards increased state control can herald more equitable distribution of their benefits. However, despite its rhetorical strength it fails to recognise the plurality of voices found within the nation itself. Because the idea of a unified state, discursively realised in both case studies, is necessarily constructed and reductive in scope, what does that mean for progressive political debate concerning resource sovereignty? We have shown how the 'one-nation' discourse rationalises resource policy but what does that mean to those voices who challenge it? What role does the language of political identity in resource frontiers (onshore and offshore, subnational, national and international etc.) play in shaping such political action? These questions, and others besides, are for future enquiries into extractivism (both 'new' and 'old') but they should all include an engagement with the politics of language and how it is translated into development strategies.

\section{Notes}

${ }^{1}$ OECD et al., Colombia Policy Priorities, 3.

${ }^{2}$ Ramirez Gallegos, Rompiendo con la Historia.

${ }^{3}$ Good Living National Plan et al.,37

${ }^{4}$ Huber, Theorizing Energy Geographies.

${ }^{5}$ Singh and Bourgouin, Resource Governance and Developmental States; Bebbington and Bury, Subterranean Struggles; and Veltmeyer and Petras, The New Extractivism.

${ }^{6}$ Hickey, Beyond the Poverty Agenda, 194.

${ }^{7}$ Prebisch, Economic Development Latin America.

${ }^{8}$ Ross, Political Economy Resource Curse; Sachs and Warner, The Curse; Auty, Sustaining Development; Stevens, Resource Impact; Weber, A Decade.

${ }^{9}$ Pillay, The Global Economic Crisis.

${ }^{10}$ Hicks, Africa's new oil.

${ }^{11}$ Bebbington and Bury, Subterranean Struggles, 54.

${ }^{12}$ UNECA, Economic Report on Africa, 8. UNECA, The Developmental State.

${ }^{13}$ Veltmeyer and Petras 2014, The New Extractivism, 22.

${ }^{14}$ Bridge, Resource Geographies.

${ }^{15}$ Grugel and Riggirozzi, Post-neoliberalism.

${ }^{16}$ Burchardt and Dietz, Neo-extractivism, 470-471.

${ }^{17}$ Gudynas, Transitions to post-extractivism.

${ }^{18}$ Bebbington et al., Political Economies; and Burchardt and Dietz, Neo-extractivism

${ }^{19}$ Arsel and Angel, Stating Nature's Role; Perrault and Valdivia, Hydrocarbons, Popular Protest.

${ }^{20}$ Quoted in Moore and Velasquez, Water for Gold, 121.

${ }^{21}$ Singh, Reconstituting the Neostructuralist State.

${ }^{22}$ Acosta, Extractivism and neoextractivism.

${ }^{23}$ Veltmeyer and Petras, The New Extractivism.

${ }^{24}$ Harvey, The New Imperialism.

${ }^{25}$ Webber, J. R., Revolution against 'Progress'.

${ }^{26}$ Grugel and Riggirozzi, Post-neoliberalism; Renfrew, The Curse of Wealth; Yates and Bakker, Debating the Post-neoliberal.

${ }^{27}$ Sum and Jessop, Towards a Cultural Political Economy; Jessop, Cultural Political Economy Policy, 336

${ }^{28}$ UNECA, Experts the Developmental State.

${ }^{29}$ Jasanoff and Kim, Sociotechnical Imaginaries, 190. 
${ }^{30}$ Grillo and Sharon, Peru's Amazonian Imaginary.

${ }^{31}$ Nesbitt and Weiner, Conflicting environmental imaginaries.

${ }^{32} \mathrm{Kohl}$ and Farthing, Material constraints.

${ }^{33}$ Baletti, Saving the Amazon.

${ }^{34}$ Beasley-Murray et al., Latin America's left turns.

${ }^{35}$ Ayelazuno, The 'new extractivism' Ghana.

${ }^{36}$ Grinspun and Mills, Canada, Extractivism.

${ }^{37}$ Kufuor, SOTN 2014, 3.

${ }^{38}$ Van Leeuwen, Legitimation in discourse.

${ }^{39}$ Weber, cited in Van Leeuwen, Legitimation in discourse, 325.

${ }^{40}$ Van Leeuwen, Legitimation in discourse, 91.

${ }^{41}$ Mahama, SOTN 2014, 891.

${ }^{42}$ Ibid., 863.

${ }^{43}$ Mills, SOTN 2010, 1298.

${ }^{44}$ Ibid, 1321.

${ }^{45}$ Van Leeuwen, Legitimation in discourse, 12.

${ }^{46}$ Mahama, SOTN 2014, 926.

${ }^{47}$ Daily News, Kikwete upbeat.

${ }^{48}$ Kiwanuka, Oil and Gas Management.

${ }^{49}$ Bhabha, The Location of Culture, 2.

${ }^{50}$ Mahama, SOTN 2014, 886. Emphasis added.

51 Ibid., 890.

${ }^{52}$ Van Leeuwen, Legitimation in discourse, 3.

53 Deneulin and Rakodi, Revisiting Religion.

${ }^{54}$ Mahama, SOTN 2014, 927.

${ }^{55}$ Wilber and Jameson, Religious Values.

${ }^{56}$ Deneulin and Rakodi, Revisiting Religion, 46

${ }^{57}$ Ibid, 48.

${ }^{58}$ See, for example, Mills 2008.

${ }^{59}$ McCaskie, USA, Ghana and Oil.

${ }^{60}$ Kufuor, SOTN 2003.

${ }^{61}$ McCaskie, USA, Ghana and Oil.

${ }^{62}$ Rieffer, Religion and Nationalism.

${ }^{63}$ Ibid, 229.

${ }^{64}$ Mahama, SOTN 2013, 882.

${ }^{65}$ Mills, SOTN 2012, 1001.

${ }^{66}$ Anderson, Imagined communities, 3.

67 Mahama, SOTN 2014, 926.

68 Ibid., 926.

${ }^{69}$ Ibid., 926.

${ }^{70}$ lbid., 926.

${ }^{71}$ Larrea, Extractivism, economic diversification in Ecuador, 1.

${ }_{72}^{7}$ Perreault \& Valdivia, Hydrocarbons and national imaginaries, 691.

73 Holst, Decolonial Dreams Ecuadorean Amazon; Alonso Gonzalez \& Macias Vazquez Debate on Buen Vivir.

${ }^{74}$ Long, Ecuador's Road to Change.

${ }^{75}$ Senplades, Good Living National Plan, 60.

${ }^{76}$ Alonso Gonzalez \& Macias Vazquez, 316.

${ }^{77}$ Ramirez Gallegos, Rompiendo con la historia.

${ }^{78}$ Else, "Natural Labs".

${ }^{79}$ Ramirez Gallegos, Hacia la independencia.

${ }^{80}$ Burchardt and Dietz, (Neo-)extractivism.

${ }^{81} \mathrm{Kim}, \mathrm{Kim} \& \mathrm{Kim}$, From Development to Cooperation.

${ }^{82}$ Cancilleria Ecuador, Milestones.

${ }^{83}$ Senplades, Good Living National Plan, 14.

${ }^{84}$ Telesur, Poll reaffirms.

${ }^{85}$ Long, In Defense. 


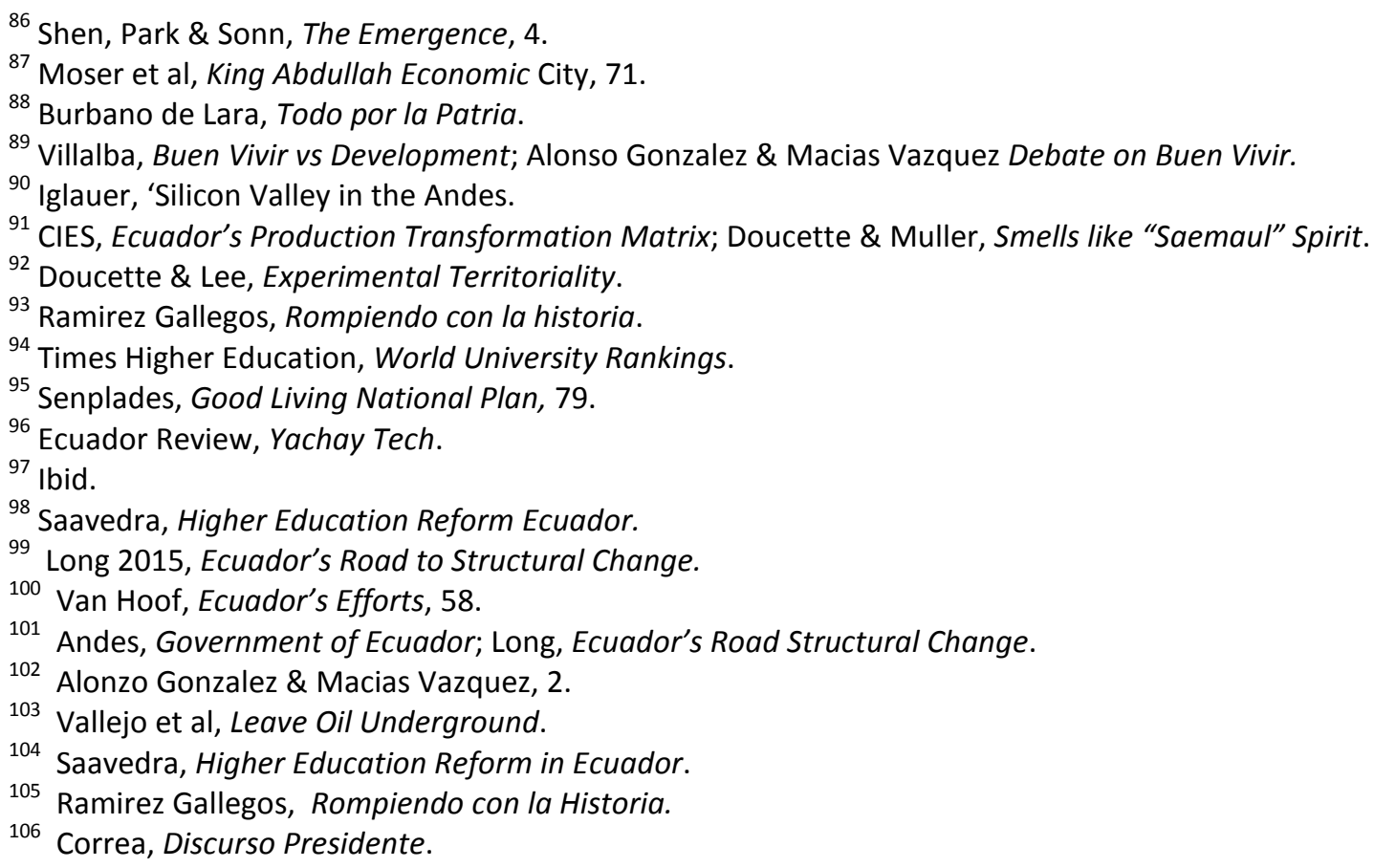

\section{Bibliography}

Acosta, A. (2013). Extractivism and neoextractivism: two sides of the same curse. Beyond Development, 61. Anderson, B. (2006). Imagined communities: Reflections on the origin and spread of nationalism. Verso Books. Andes (2014) 'Government of Ecuador Delivered Scholarship No. 10 thousandth to Study Abroad', 17 December.

Arsel, M., \& Angel, N. A. (2012). "Stating" Nature's Role in Ecuadorian Development Civil Society and the Yasuní-ITT Initiative. Journal of Developing Societies, 28(2), 203-227.

Auty, R. (2002). Sustaining development in mineral economies: the resource curse thesis. Routledge.

Ayelazuno, J. A. (2014). The 'new extractivism'in Ghana: A critical review of its development prospects. The Extractive Industries and Society, 1(2), 292-302.

Beasley-Murray, J., Cameron, M. A., \& Hershberg, E. (2009). Latin America's left turns: an introduction. Third World Quarterly, 30(2), 319-330.

Bebbington, A., \& Bury, J. (2013). Subterranean Struggles: New Dynamics of Mining, Oil, and Gas in Latin America (No. 8). University of Texas Press.

Bebbington, A., Bornschlegl, T., \& Johnson, A. (2013). Political economies of extractive industry: from documenting complexity to informing current debates. Development and Change.

Bhabha, H. K. (1994). The location of culture. London: Psychology Press.

Burbano de Lara, F. (2015) 'Todo por la Patria. Refundacion y retorno del estado en las Revoluciones Bolivarianas' 'Everything for the Nation: The Re-founding and Return of the State in the Bolivarian Revolutions', Iconos 52: 19-41.

Burchardt, H. \& Dietz, K. (2014) '(Neo-)extractivism - a New Challenge for Development Theory from Latin America', Third World Quarterly 35(3): 468-86.

Bridge, G. (2014a) "Resource geographies II The resource-state nexus." Progress in Human Geography 38(1): 118-130

cancilleria.gob.ec 'Milestones of the Citizen Revolution (2007-2013)'.

CIES (2013) Ecuador's Production Transformation Matrix.

Correa, R. (2014) 'Discurso Presidente Rafael Correa al Recibir Honoris Causa de la Universidad de Chile', University of Santiago in Chile, 13 May.

Daily News (2013) 'Kikwete upbeat on gas discoveries', Tanzania Daily News, available online at http://allafrica.com/stories/201307090597.html

de la Torres, C. (2013) 'Technocratic Populism in Ecuador', Journal of Democracy 24(3): 33-46.

Deneulin, S., \& Rakodi, C. (2011). Revisiting religion: development studies thirty years on. World Development, 39(1), 45-54. 
Doucette, J. \& Lee, O-S. (2015) 'Experimental Territoriality: Assembling the Kaesong Industrial Complex in North Korea', Political Geography 47.

Doucette, J. \& Muller, A. (2015) 'Smells like Saemaul spirit: South Korea's Knowledge Sharing Program and the "Rendering Technical" of Korean Development', unpublished paper.

Else, H. (2014) “"Natural labs” a Magnet for Ecuador's City of Knowledge', Times Higher Education 16 October. Ecuador Review (2015) 'Yachay Tech: Waiting for Transparent Accounting', 18 August.

Fuchs, G. (2015) 'Ecuador's Opposition and Right-wing Strategies in the Region', teleSUR, 2 July.

Gallegos, F. (2015) 'Political Change, State Autonomy and Post-neoliberalism in Ecuador, 2007-2012', Latin American Perspectives, 42(3).

Grillo, M. T., \& Sharon, T. (2012). Peru's Amazonian Imaginary. Environment and Citizenship in Latin America: Natures, Subjects and Struggles, 101, 112.

Grinspun, R., \& Mills, J. (2015). Canada, Extractivism, and Hemispheric Relations. Beyond Free Trade: Alternative Approaches to Trade, Politics and Power, 133.

Gudynas, E. (2013). Transitions to post-extractivism: directions, options, areas of action. Beyond Development, 165.

Harvey, D. (2003). The new imperialism. Oxford University Press.

Hickey, S. (2013). Beyond the poverty agenda? Insights from the new politics of development in Uganda. World Development, 43, 194-206.

Hicks, C. (2015). Africa's new oil: power, pipelines and future fortunes.

Holst, J. (2015) 'Colonial Histories and Decolonial Dreams in the Ecuadorean Amazon: Natural Resources and the Politics of Post-Neoliberalism', Latin American Perspectives.

Huber, M. (2015). Theorizing Energy Geographies. Geography Compass, 9(6), 327-338.

Iglauer, P. (2013) 'Silicon Valley in the Andes', The Korea Herald, 31 March.

Jessop, B. (2010). Cultural political economy and critical policy studies. Critical policy studies, 3(3-4), 336-356.

Grugel J. and Riggirozzi P. (2012) 'Post-neoliberalism in Latin America: Rebuilding and reclaiming the state after crisis'. Development and Change 43(1): 1-21.

Gudynas, E. (2011) 'Buen Vivir: Today's tomorrow', Development 54(4), 441-447

Kim, Kim \& Kim (2013) 'From Development to Development Cooperation: Foreign Aid, Country Ownership and the Developmental State in South Korea', The Pacific Review 26(3): 313-36.

Kiwanuka (2013) 'Oil and Gas Management for Inclusive and Sustainable Development: An East African Regional Forum', report available online at http://www.brookings.edu/ /media/research/files/papers/2013/3/07\%20oil\%20gas\%20management\% 20africa/0307\%20\%20nrm\%20conference.pdf

Kohl, B., \& Farthing, L. (2012). Material constraints to popular imaginaries: The extractive economy and resource nationalism in Bolivia. Political Geography, 31(4), 225-235.

Kufuor, J. (2003), 'State of the Nation Address', a national address given by the president at the Ghana Parliament House, Accra

Kufuor, J. (2007), 'State of the Nation Address', a national address given by the president at the Ghana Parliament House, Accra

Larrea, C. (2013) 'Extractivism, Economic Diversification and Prospects for Sustainable Development in Ecuador', Universidad Andina Simon Bolivar.

Long, G. (2015a) 'Ecuador's Road to Structural Change: Accomplishment and Future Challenges', University of London, 22 January 2015.

Long, G. (2015b) 'In Defense of Rafael Correa', Jacobin Magazine, September.

Macias Vazquez, A. \& Alonso Gonzalez, P. (2015) 'An Ontological Turn in the Debate on Buen Vivir - Sumak Kawsay in Ecuador: Ideology, Knowledge and the Common', Latin American and Caribbean Ethnic Studies.

Mahama, J. (2013), 'State of the Nation Address', a national address given by the president at the Ghana Parliament House, Accra

Mahama, J. (2014), 'State of the Nation Address', a national address given by the president at the Ghana Parliament House, Accra

McCaskie, T. C. (2008). The United States, Ghana and oil: Global and local perspectives. African Affairs, 107(428), 313-332.

Mills, J.A. (2008), 'State of the Nation Address', a national address given by the president at the Ghana Parliament House, Accra 
Mills, J.A. (2010), 'State of the Nation Address', a national address given by the president at the Ghana Parliament House, Accra

Mills, J.A. (2012), 'State of the Nation Address', a national address given by the president at the Ghana Parliament House, Accra

Moore, J., \& Velásquez, T. (2012). Water for gold: confronting state and corporate mining discourses in Azuay, Ecuador. Subterranean Struggles: New Geographies of Extractive Industries in Latin America. University of Texas, Austin.

Moser, S; Swain, M. \& Alkhabbaz, M. (2014) ‘King Abdullah Economic City: Engineering Saudi Arabia's Post-Oil Future', Cities 45: 71-80.

Nem Singh, J. T. (2010). Reconstituting the Neostructuralist State: the political economy of continuity and change in Chilean mining policy. Third World Quarterly, 31(8): 1413-1433.

Nesbitt, J. T., \& Weiner, D. (2001). Conflicting environmental imaginaries and the politics of nature in Central Appalachia. Geoforum, 32(3), 333-349.

OECD 2015 http://www.oecd.org/about/publishing/colombia-policy-priorities-for-inclusive-development.pdf

Owens, B. (2015) 'Qatar Forges Ahead with Science Vision', The Lancet 385, 10 January.

Pennsylvania State University (2014) http://science.psu.edu/news-and-events/2014-news/Larson10-2014

Perez Ordonez, P. (2010) ‘El Presidente Rafael Correa y Su Politica de Redencion', 'President Rafael Correa and his Politics of Redemption', Ecuador Debate 80: 77-94.

Perreault T and Valdivia G (2010) 'Hydrocarbons, popular protest and national imaginaries: Ecuador and Bolivia in comparative context'. Geoforum 41(5): 689-699.

Pillay, D. (2015). The Global Economic Crisis and the Africa Rising Narrative. Africa Development, 40(3), 59-75.

Prebisch AMERICA, O. L. (1950). The economic development of Latin America and its principal problems.

Ramirez Gallegos, R. (2014a) 'Rompiendo con la historia: (la) generacion Yachay! Discurso de la Inauguracion de la Universidad Experimental Yachay’, 31 March 2014.

Ramirez Gallegos, R. (2014b) 'Hacia la Independencia Intelectual', January 2014.

Renfrew, D. (2011). The curse of wealth: Political ecologies of Latin American neoliberalism. Geography Compass, 5(8), 581-594.

Rieffer, B. A. J. (2003). Religion and Nationalism Understanding the Consequences of a Complex Relationship. Ethnicities, 3(2), 215-242.

Ross, M. L. (1999). The political economy of the resource curse. World politics, 51(02), 297-322.

Saavedra, M. (2012) 'Higher Education Reform in Ecuador and Its Effect on University Governance' in Schuetze, $\mathrm{H}$. et al (eds) University Governance and Reform, New York: Palgrave Macmillan.

Sachs, J. D., \& Warner, A. M. (2001). The curse of natural resources. European economic review, 45(4), 827838.

Senplades (2013) 'Good Living National Plan 2013-2017', Quito: Senplades.

Shen, H; Park, S \& Sonn, J. (2016) 'The Emergence of a Multi-Scalar Growth Regime and Scalar Tension: The Politics of Urban Development in Songdo New City, South Korea', Environment and Planning C: Government and Policy 34(1).

Singh, J. N., \& Bourgouin, F. (Eds.). (2013). Resource Governance and Developmental States in the Global South: Critical International Political Economy Perspectives. Palgrave Macmillan.

Stevens, P. (2003). Resource impact: curse or blessing? A literature survey.

Sum, N. L., \& Jessop, B. (2013). Towards a cultural political economy: putting culture in its place in political economy. Edward Elgar Publishing.

Telesur (2015) 'Poll Reaffirms Two-Thirds of Ecuadoreans Support Correa', 15 July.

The Business Year (2014) 'Knowledge City: Investigate! Innovate! Produce!' www.thebusinessyear.com/ecuador-2014/knowledge-city-investigate-innovate-produce, October 2014.

Times Higher Education (2015) 'World University Rankings' https://www.timeshighereducation.co.uk/worlduniversity-rankings/2015/world-ranking/\#/

UNECA 2013 http://www1.uneca.org/ArticleDetail/tabid/3018/Articleld/2493/Experts-discuss-theDevelopmental-State-and-underscore-its-role-in-the-socio-economic-transformation-of-thecontinent.aspx

UNECA 2015 http://www.uneca.org/publications/economic-report-africa-2015

Vallejo, M. Burbano, R, Falconi, F. \& Larrea, C. (2015) 'Leaving Oil Underground in Ecuador: The Yasuni-ITT Initiative from a Multi-Criteria Perspective', Ecological Economics 109: 175-85.

Van Hoof, H. (2015) 'Ecuador's Efforts to Raise Its Research Profile: The Prometeo Program Case Study', Journal of Hispanic Higher Education 14(1): 56-68. 
Van Leeuwen, T. (2007). Legitimation in discourse and communication. Discourse \& Communication, 1(1), 91112.

Veltmeyer, H., and J. Petras. (2014) The New Extractivism in Latin America. Zed: London

Villalba, U. (2013) 'Buen Vivir vs Development: A Paradigm Shift in the Andes?' Third World Quarterly 34(8): 1427-42.

Webber, J. R. (2014). Revolution against 'Progress': Neo-Extractivism, the Compensatory State, and the TIPNIS Conflict in Bolivia. Crisis and Contradiction: Marxist Perspectives on Latin America in the Global Political Economy, 302.

Weber, M. (1964) The Theory of Social and Economic Organization. New York: The Free Press.

Weber, J. G. (2014). A decade of natural gas development: The makings of a resource curse?. Resource and Energy Economics, 37, 168-183.

Yachay Tech (2015) http://yachaytech.edu.ec/en/yachay-tech/history/

Yates, J. S., \& Bakker, K. (2013). Debating the 'post-neoliberal turn'in Latin America. Progress in Human Geography, 0309132513500372. 